\title{
Reproductive Knowledge, Attitudes and Behavior Among Adolescent Males in Tehran, Iran
}

\begin{abstract}
CONTEXT: Iran's culture and religion prohibit sexual contact prior to marriage. Due to the sensitivity of the topic, little is known about the sexual activity of unmarried adolescent males or about their knowledge of, and attitudes toward, sexuality and reproductive health.
\end{abstract}

METHODS: A population-based study of 1,385 males aged 15-18 in Tehran was conducted using a self-administered questionnaire. Participants were questioned about their beliefs and knowledge regarding reproductive health, and asked whether they had engaged in sexual activity. Bivariate and multivariate analyses were performed to identify factors associated with sexual knowledge, attitudes and behavior.

RESULTS: Twenty-eight percent of the sample reported having engaged in sexual activity. Sexual experience was associated with older age, access to satellite television, alcohol consumption and permissive attitudes toward sex. Substantial proportions of respondents held misconceptions regarding condoms, STIs and reproductive physiology. Attitudes toward premarital sex were more permissive among respondents who were older, were not in school, had work experience, had access to the Internet or satellite television, lived separately from their parents, or reported having used alcohol, cigarettes or drugs.

CONCLUSION: The relatively high prevalence of sexual activity and the lack of knowledge regarding STIs and contraceptives pose a significant threat to the sexual and reproductive health of adolescent males in Iran. Programs are needed to provide adolescents with the information and skills to make safe sexual decisions.

International Family Planning Perspectives, 2006, 32(1):35-44

Young people constitute a significant proportion of the Iranian population. In the most recent national census (1996), there were approximately 16 million adolescents aged $10-19$, accounting for $25 \%$ of the Iranian population, and 21 million young people aged 10-24, accounting for more than one third of the population. ${ }^{1}$

Due to such factors as a rapid increase in age at first marriage, there has been a sharp decline in the proportion of postpubescent young people who are married. Between 1986 and 1996, mean age at first marriage rose from 19.8 to 22.4 among females and from 23.6 to 25.6 among males; ${ }^{2}$ as a result, the proportion of adolescent females aged 15-19 who had ever been married fell from 33\% to 19\%, a 44\% decline. ${ }^{3}$ These data suggest a widening window during which young people may engage in potentially risky premarital sexual activities.

Despite this trend, little is known about the reproductive health needs of young people in Iran. Although some smalland large-scale investigations have been conducted, these studies, due to cultural sensitivities, have avoided sensitive topics such as attitudes about sexual relations, the prevalence of risky sexual behaviors, and rates of STIs. Instead, researchers have focused on topics such as puberty in girls and opinions on family planning. ${ }^{4}$

Cultural sensitivities may also be a factor in young people's poor knowledge about reproductive health. In Iran, few programs provide sexuality education to adolescents or enable youth to ask questions and correct misconceptions about reproductive health. Indeed, large numbers of young Iranians lack information about safe sex and about the skills necessary to negotiate and adopt safe sex practices.

Recently, the Iranian government has recognized the importance of addressing the reproductive health needs of adolescents and youth; it has undertaken a review of relevant policies and approaches, and efforts are under way to design programs that meet these needs in an acceptable and sensitive manner. ${ }^{5}$ However, these efforts are hampered by the current lack of data regarding the reproductive health, attitudes, sexual behavior and related needs of unmarried young people.

This paper reports findings from a pioneering, population-based study that aimed to break the silence on adolescent reproductive health in Iran and to fill important information gaps regarding sexual behavior and associated factors among male adolescents in Tehran. The study was implemented by a multidisciplinary team of investigators and sought to determine adolescents' knowledge, attitudes and behaviors related to a wide range of reproductive health topics and gender issues. It was designed to provide data that can inform the creation of programs and policies to address the sexual and reproductive health needs of young people in Iran.
ByMohammad Reza Mohammadi, Kazem Mohammad, Farideh K.A.

Farahani,

Siamak Alikhani, Mohammad Zare, Fahimeh R. Tehrani, Ali Ramezankhani and Farshid Alaeddini.

Mohammad Reza Mohammadi is chair, child and adolescent psychiatry, Tehran University of Medical Sciences, and director, National Research Centre of Medical Sciences of Iran. Kazem Mohammad is chair, epidemiology and biostatistics, Tehran University of Medical Sciences. Farideh K. A. Farahani is a doctoral candidate, London School of Hygiene and Tropical Medicine. Siamak Alikhani is director, Noncommunicable Disease Surveillance System; Mohammad Zare is epidemiologist, Centre for Disease Control; and Fahimeh R. Tehrani is head, Reproductive Health Research Unit-all at the Ministry of Health and Medical Education, Tehran. Ali Ramezankhani is assistant professor of health education, Shaheed Beheshti University, Tehran. Farshid Alaeddini is deputy, Ministry of Research, National Research Center for Medical Sciences of Iran. 


\begin{tabular}{|c|c|c|c|}
\hline Characteristic & $\begin{array}{l}\% \\
(N=1,385)\end{array}$ & Characteristic & $\begin{array}{l}\% \\
(\mathrm{~N}=1,385)\end{array}$ \\
\hline \multicolumn{2}{|l|}{ Age } & \multicolumn{2}{|l|}{ Communication with father on sex§ } \\
\hline $15-16$ & 48.3 & Frequent & 11.3 \\
\hline \multirow[t]{2}{*}{$17-18$} & 51.7 & Rare & 20.1 \\
\hline & & None & 68.6 \\
\hline \multicolumn{4}{|l|}{ Current school attendance } \\
\hline Day school & 76.3 & \multicolumn{2}{|c|}{ Communication with mother on important matters $+\dagger$} \\
\hline Night school & 4.4 & Easy & 31.1 \\
\hline \multirow{2}{*}{ None } & 19.3 & Moderate & 34.0 \\
\hline & & Difficult & 34.9 \\
\hline \multicolumn{4}{|l|}{ Type of school attended } \\
\hline Governmental & 76.6 & Communication with mother on sexf‡ & \\
\hline Nongovernmental & 9.4 & Frequent & 11.7 \\
\hline \multirow{2}{*}{ Both } & 14.0 & Rare & 25.0 \\
\hline & & None & 63.3 \\
\hline \multicolumn{4}{|l|}{ Ever worked } \\
\hline Yes & 47.0 & Has older brother & \\
\hline \multirow[t]{2}{*}{ No } & 53.0 & Yes & 54.8 \\
\hline & & No & 45.2 \\
\hline \multicolumn{4}{|l|}{ Currently workingt } \\
\hline Yes & 58.9 & Has older sister & \\
\hline \multirow[t]{2}{*}{ No } & 41.1 & Yes & 56.1 \\
\hline & & No & 43.9 \\
\hline \multicolumn{4}{|l|}{ Religion } \\
\hline Muslim & 97.7 & Has access to satellite television & \\
\hline Christian & 1.5 & Yes & 27.0 \\
\hline Other & 0.8 & No & 73.0 \\
\hline Religiosity & & Has access to Internet & \\
\hline Religious & 79.7 & Yes & 34.3 \\
\hline Somewhat religious & 15.4 & No & 65.7 \\
\hline \multirow[t]{2}{*}{ Not religious } & 4.9 & & \\
\hline & & Ever smoked & \\
\hline Lives with parents & & Yes & 12.8 \\
\hline Both & 88.7 & No & 87.2 \\
\hline One & 10.0 & & \\
\hline \multirow[t]{2}{*}{ Neither } & 1.3 & Ever used alcohol & \\
\hline & & Yes & 16.8 \\
\hline Father & & No & 83.2 \\
\hline Alive & 94.3 & & \\
\hline \multirow[t]{2}{*}{ Dead } & 5.7 & Ever used drugs & \\
\hline & & Yes & 2.1 \\
\hline Communication with father on important mattersł & & No & 97.9 \\
\hline Easy & 47.0 & & \\
\hline Moderate & 32.3 & Total & 100.0 \\
\hline Difficult & 20.7 & & \\
\hline
\end{tabular}

\section{DESIGN AND METHODOLOGY Sample Selection}

Data for this article were collected in 2002 from males aged 15-18 who lived in Tehran. The rationale for focusing on Tehran was twofold. First, the population of Tehran constitutes about one-fifth of the Iranian population and encompasses all of the country's socioeconomic and ethnic groups; therefore, the study population represents a heterogeneous group of youth. Second, Tehran is a major urban area whose population is more likely than residents of rural regions to be exposed to new ideas and opportunities, including those related to sex.

The sample was derived through cluster sampling of the 22 main municipal sectors of Tehran from July to September 2002. Clusters were selected randomly, in proportion to the estimated population of each sector, from among the existing blocks provided by the Statistical Centre of Iran. From each cluster, we selected 10 households in which at least one male in our target age-group resided. All males aged 15-18 in these households were invited to participate in the study.

We recruited a total of 1,500 adolescent males. Of these, 1,385 completed the questionnaire, yielding a response rate of $92 \%$. Of the 115 remaining adolescents, 50 declined to participate or were not permitted to participate by their parents, and 65 completed questionnaires that had to be discarded because of substantial inconsistency (e.g., multiple responses to key questions).

\section{Questionnaire}

The survey instrument was adapted from a core questionnaire developed by the World Health Organization; ${ }^{6}$ it was modified to be self-administered, to conform to cultural sentiments and to incorporate insights gained from the study's exploratory phase. The questionnaire comprised 89 questions divided into six sections: social and demographic vari- 
ables; knowledge about reproductive physiology; awareness of contraceptive methods (especially condoms); awareness of STIs and AIDS; attitudes about relationships between the sexes; and, finally, sexual behaviors and experiences.

Several measures were taken to ensure confidentiality. The questionnaire was self-administered, and interviewers asked the respondents not to identify themselves. Informed consent was obtained from one parent as well as from the respondent; however, the adolescents were assured that neither the interviewer nor their parents would have access to their responses. Completed questionnaires were placed in sealed boxes.

The questionnaire covered several aspects of the young men's knowledge, attitudes and behaviors related to reproductive health.

-Knowledge about reproductive physiology. The adolescents were asked to assess the accuracy of three statements on reproductive physiology, namely, that a woman can become pregnant at first intercourse, that a woman stops growing after first intercourse and that pregnancy is most likely to occur in midcycle. We devised a summary index that assigned a score of 1 for each correct response and 0 for each incorrect or "don't know" response, yielding a total score ranging from 0 to 3.

-Knowledge of contraceptive methods. We assessed respondents' familiarity with 10 contraceptive methods, both common (sterilization, IUD) and uncommon (jelly). The summary index, ranging from 0 to 10 , assigned one point for each method known.

-Knowledge about condoms. The respondents were asked the accuracy of three statements: that condoms can be used more than once, that they protect against STIs and that they are effective in preventing pregnancy. Again, the summary score ranges from 0 to 3 .

-Awareness of HIV/AIDS and STIs. The young men were asked whether they had heard of STIs and AIDS. They were also asked if it is possible to cure AIDS and if an HIVinfected person always looks unhealthy. Responses were scored 1 if correct and 0 if not. In addition, we asked the adolescents whether three symptoms indicate the presence of STIs for men and women, respectively; again, each correct response (out of 6) was coded 1 and each incorrect or non-response was coded 0 . In total, therefore, scores on the STI/HIV/AIDS awareness index range from 0 to 9 .

-Attitudes toward premarital sex. Respondents were asked how much they agreed or disagreed with six statements. In deference to cultural sensitivities, statements deliberately reflected societal norms (for example, "Unmarried young people should not have sex"). The responses, which ranged from "completely agree" to "completely disagree," were converted into five-point Likert scales (ranging from 1 for extremely conservative views to 5 for extremely liberal views). A summary index provides the average of the scores on the six measures.

-Sexual contact. Given the sensitivity of the topic, we asked the adolescents only a few questions regarding their sexual experience. Participants were asked whether they had
TABLE 2. Percentage distribution of adolescent males aged 15-18, by responses to statements about aspects of reproductive health

\begin{tabular}{lrrrr} 
Aspect & Yes & No $\begin{array}{c}\text { Do not } \\
\text { know }\end{array}$ & Total \\
\hline Reproductive physiology & & & & \\
A woman can get pregnant at first intercourse & 73.5 & 18.5 & 38.0 & 100.0 \\
A woman stops growing after first intercourse & 16.9 & 96.4 & 56.3 & 100.0 \\
Pregnancy is most likely to occur in midcycle & & & & 100.0 \\
& & & & \\
Condoms & 5.3 & 54.8 & 40.0 & 100.0 \\
Condoms can be used more than once & 42.4 & 10.5 & 47.1 & 100.0 \\
Condoms are an effective way of protecting against STIs & 53.0 & 10.0 & 37.0 & 100.0 \\
Condoms are an effective method of preventing pregnancy & & & & \\
& & & & \\
STIs and AIDS & 16.6 & 62.6 & 20.7 & 100.0 \\
It possible to cure AIDS & & & & \\
A person with HIV always looks emaciated or unhealthy & 6.1 & 76.9 & 17.0 & 100.0 \\
$\quad$ in some way & 28.3 & 9.4 & 62.3 & 100.0 \\
Discharge and blood from the genitals are a sign of an STI in a man & 34.2 & 10.5 & 55.2 & 100.0 \\
Pain during urination is a sign of an STI in a man & 28.2 & 9.9 & 61.9 & 100.0 \\
Ulcers/sores in the genital area are a sign of an STI in a man & & & & \\
Discharge and blood from the genitals are a sign of an STI & 21.2 & 6.9 & 71.9 & 100.0 \\
$\quad$ in a woman & 19.4 & 8.7 & 71.9 & 100.0 \\
Pain during urination is a sign of an STI in a woman & 21.0 & 6.9 & 72.1 & 100.0
\end{tabular}

ever had sexual contact with a young woman and, if so, the number of partners they had and the type of contraceptive used. No probing or follow-up questions were asked regarding the nature of the sexual experience; hence, responses referred to both nonpenetrative experiences (hugging, kissing and touching) and penetrative sexual activity.

\section{Data Analysis}

Study data were analyzed using SPSS-11. T-tests and chisquare tests were employed for bivariate analysis, and logistic regression was used for multivariate analysis.

\section{RESULTS \\ Respondent Characteristics}

Of the 1,385 young men in the sample, about half were aged 15-16 and half 17-18 (Table 1); the mean age was 16.6. The majority (81\%) were attending school, usually in governmental institutions during the day (in general, students who attend night school in Iran do so because they have daytime jobs or are married). Almost half reported that they had ever been employed, and 28\% were currently working; seventeen percent were combining schooling with work. Nearly all respondents were Muslim, and 80\% considered themselves to be highly religious. Relativity few participants reported ever having smoked (13\%) or used alcohol (17\%) or drugs (2\%).

Although we were unable to determine the adolescents' exposure to pornography, we were able to ask about their access to satellite TV and the Internet, media through which pornographic materials may be accessible (if a private Internet service provider is used; the main government-sponsored provider has firewalls that prevent access to pornographic Web sites). ${ }^{7}$ Responses indicated that one-fourth of participants had access to satellite TV and one-third had Internet access.

The survey also inquired about the ease with which, and 
TABLE 3. Mean scores of adolescent males on reproductive health knowledge indices, by selected social and demographic characteristics

Characteristic Reproductive Contraceptives STIs and Condoms

\begin{tabular}{lllll} 
& \multicolumn{3}{l}{ physiology } & \multicolumn{3}{l}{ HIV/AIDS } \\
\hline All & $\mathbf{0 . 9 7}$ & $\mathbf{3 . 1 4}$ & $\mathbf{3 . 8 6}$ & $\mathbf{1 . 5 0}$
\end{tabular}

Age

$15-16$

$17-18$

$\begin{array}{llll}0.76^{*} & 2.68^{*} & 3.41^{*} & 1.11^{*}\end{array}$

Current school attendance

Day school

Night school

None

Type of school attended

Governmental

Nongovernmental

Both

3.57

4.28

186

Ever worked

Yes

No

Religiosity

Religious

Somewhat religious

Not religious

Lives with parents

Both

One

Neither

$\begin{array}{llll}0.93^{*} & 3.09^{*} & 3.83 & 1.42^{*}\end{array}$

1.10

$\begin{array}{llll}1.10 & 3.91 & & \\ 1.09 & 3.13 & 3.86 & 1.69\end{array}$

Communication with father on important matters

Easy

Moderate

Difficult

0.95

1.00

3.09

3.14
3.49

$3.75^{*}$

$3.75^{*}-1.47$

$4.11 \quad 1.61$

$4.30 \quad 1.56$

$\begin{array}{llll}1.01 & 3.32^{*} & 3.96 & 1.63^{*}\end{array}$

0.93

2.99

3.78

1.40

Communication with father on sex

Frequent

Rare

None

$0.90^{*}$

1.15

$3.00^{*}$

$$
3.69
$$

3.76

$3.70^{*}$

$4.51-1.41 *$

$4.47 \quad 2.00$

$3.94^{*} \quad 3.08^{*}$

$0.94^{*}$

1.09

3.08
3.55

4.27

3.88

4.07

4.67

1.48

1.68

$0.97^{*} \quad 2.96^{*}$

0.81

1.10

3.11

3.33

3.86

3.68

3.68
3.99

1.47

1.41

1.60

Communication with mother on important matters

Easy

Moderate

Difficult

$1.17^{*}$

0.90

0.92

$3.08^{*}$

$$
3.42
$$

3.00

4.03

1.47

$4.00-1.41$

$3.75 \quad 1.60$

$3.86^{*} \quad 1.45^{*}$

$3.65 \quad 1.42$

$\begin{array}{ll}4.05 & 1.65\end{array}$

Communication with mother on sex

Frequent

Rare

None

0.97

1.06

0.93

\section{$2.94^{*}$}

$$
3.46
$$

Has older brother

Yes

0.96

0.96
0.97

3.16

3.12

0.96

Yes
No

Has access to satellite televison

Yes

No

Has access to Internet

Yes

No

Ever smoked

Yes

No

Ever used alcohol

Yes

No

Ever used drugs

Yes

No

${ }^{*} p<.05$. the degree to which, the adolescents communicated with parents on sensitive matters. The vast majority of participants (89\%) reported living with both parents; $10 \%$ lived with only one parent and 1\% with neither parent. Some 47\% found it easy to communicate with their father on important issues, and 31\% had ever talked with their father about sexual matters. Similarly, fewer than a third of participants found it easy to communicate with their mother on important issues, and 37\% had ever discussed sexual matters with their mother.

\section{Reproductive Health Knowledge}

Participants' knowledge of reproductive health issues varied widely, but misperceptions were common (Table 2, page 37). About $44 \%$ of respondents knew that a woman can get pregnant at first intercourse, and 17\% were aware that pregnancy is most likely to occur in midcycle. Slightly more than a third (36\%) knew that a woman does not stop growing after first intercourse.

Similarly, although nearly three in four adolescents were aware of condoms, few had in-depth knowledge. About half knew that condoms cannot be used more than once and that they are effective for preventing pregnancy. Fewer (42\%) knew that condom use can prevent STIs. Twenty-six percent thought that the use of condoms reduces sexual pleasure (data not shown).

Nearly all (95\%) of the respondents had heard about STIs and HIV/AIDS, but misconceptions were widespread. For example, $37 \%$ of the young men did not know that AIDS is not curable, and 23\% did not know that people infected with HIV can be asymptomatic. Familiarity with the signs and symptoms of STIs was poor; relatively small proportions of respondents knew that likely symptoms of STIs in men include discharge from the penis (28\%), pain during urination (34\%), and ulcers/sores in the genital area (28\%). Respondents' knowledge of signs and symptoms in females was even lower.

Almost three-quarters (72\%) of participants were aware of condoms (not shown), although more than half (53\%) had never seen one. In general, respondents were more likely to be aware of contraceptive methods appropriate for youth, such as condoms and oral contraceptives (58\%), than of methods such as the IUD (22\%) and the injectable (14\%). Still, $53 \%$ and $41 \%$ were aware of female and male sterilization, respectively. Familiarity was low for other methods, including emergency contraception (16\%), withdrawal (14\%), jelly or foam (13\%) and the implant (12\%). Thirteen percent of adolescents were not familiar with any contraceptive method.

Table 3 summarizes respondents' scores on the various knowledge indices. Among all participants, the mean score on the three-point reproductive physiology index was 0.97 ( $\mathrm{SD}=0.92$ ), suggesting poor to moderate levels of awareness. Contraceptive knowledge was not much better. Of the 10 methods, respondents were aware, on average, of 3.14 ( $\mathrm{SD}=2.36)$. Mean scores were moderate on the the nine-point STI/HIV/AIDS scale (3.86; SD=2.13) and the three-point condom awareness index (1.50; SD=1.20). The adolescents' 
relatively superior knowledge of HIV/AIDS may have been due to a youth-oriented educational AIDS campaign that was broadcast on television at the time of the study.

Bivariate analyses identified a number of factors associated with reproductive health knowledge, including age, schooling status, type of school and work status. Access to satellite television and to the Internet were positively associated with awareness. Religiosity, on the other hand, was inversely associated with knowledge: For all topics, adolescents who did not consider themselves devout displayed better knowledge about reproductive health than those who labeled themselves religious. Curiously, communication with parents about important matters or about sexual issues was not associated with enhanced awareness levels; indeed, those who reported difficulty in communicating with parents appeared to be more knowledgeable than other youth about reproductive health issues. (However, frequent communication with fathers on sexual issues was associated with greater awareness of reproductive physiology.) Also notable is the positive association between use of cigarettes, alcohol or drugs and knowledge of reproductive health, a relationship that probably reflected the fact that older respondents were more likely both to use these substances and to be knowledgeable about reproductive health.

Consistent with the adolescents' infrequent and often difficult communication with parents on sexual issues, only $27 \%$ of respondents reported that their mother or father was their primary source of information about the physical and psychological changes of puberty; nearly identical proportions of participants cited friends and classmates (26\%) or teachers and school counselors (25\%) as their main source (Table 4). Adolescents' preferred sources of information about puberty mirrored the actual sources, although parents (17\%) were slightly less likely than peers (20\%) or teachers (21\%) to be cited. Twelve percent of adolescents said that books and magazines were their preferred source of information on puberty.

For information on sexual matters, the pattern was even more skewed. When asked to name their most important source of information and their preferred source of information on sex, respondents most often cited peers (34\% and $21 \%$, respectively) or teachers (21\% and $15 \%$, respectively). Books and magazines were the preferred source of $15 \%$ of the respondents. Relatively few adolescents cited their parents as their most important (16\%) or preferred (12\%) source of information on sex.

\section{Attitudes Toward Premarital Sex}

Table 5 reports respondents' views on six statements regarding premarital sex. The majority (55\%) of adolescents believed (agreed or completely agreed) that unmarried young men and women should not have sex; 34\% felt that unmarried members of the opposite sex should not even form friendships. Seventy-six percent believed that homosexual behavior is unacceptable.

Several gender disparities were apparent. For example, $56 \%$ of adolescent males completely agreed that young

\begin{tabular}{|c|c|c|c|c|}
\hline \multirow[t]{2}{*}{ Source } & \multicolumn{2}{|l|}{ Puberty } & \multicolumn{2}{|l|}{ Sex } \\
\hline & $\begin{array}{l}\text { Most } \\
\text { important }\end{array}$ & Preferred & $\begin{array}{l}\text { Most } \\
\text { important }\end{array}$ & Preferred \\
\hline Mother & 15.1 & 7.1 & 9.0 & 4.8 \\
\hline Father & 12.0 & 10.3 & 7.0 & 6.9 \\
\hline $\begin{array}{l}\text { Siblings/other } \\
\text { family members }\end{array}$ & 7.4 & 9.2 & 6.4 & 5.4 \\
\hline Classmates/friends & 25.6 & 19.7 & 34.1 & 21.4 \\
\hline $\begin{array}{l}\text { Teacher/school } \\
\text { counselor/class } \\
\text { Physician/other }\end{array}$ & 25.2 & 20.8 & 20.7 & 15.0 \\
\hline health care provide & ler 0.9 & 5.8 & 3.0 & 9.7 \\
\hline Books/magazines & 7.5 & 12.2 & 9.2 & 14.5 \\
\hline Videos/films & 2.5 & 5.9 & 4.9 & 9.1 \\
\hline Radio/television & 1.9 & 4.6 & 3.7 & 5.3 \\
\hline Other & 1.9 & 4.4 & 2.0 & 7.9 \\
\hline Total & 100.0 & 100.0 & 100.0 & 100.0 \\
\hline
\end{tabular}

women should not have sex before marriage, but only $41 \%$ held the same view about members of their own sex. Moreover, respondents were more likely to believe that young women who engaged in premarital sex would later regret it than they were to believe that adolescent males would do so (43\% vs. $32 \%$; data not shown).

Several other questions regarding sexual attitudes were posed to participants, although the responses were not included in the attitudinal index. For example, 53\% of respondents declared that masturbation is harmful to human well-being; only 14\% disagreed. We also found that $40 \%$ of the young men approved of temporary marriage, a controversial but permissible type of union whose duration and corresponding bride price are specified in advance in the marriage contract.

Table 6 (page 40) examines the bivariate relationships between social and demographic characteristics and scores on the summary index of attitudes. For this index, responses to the six questions in Table 5 were converted to a Likert scale ranging from 1 (most conservative) to 5 (most permissive) and then averaged; the mean score of 2.44 $(\mathrm{SD}=0.96)$ falls near the midpoint of the index. Older re-

TABLE 5. Percentage distribution of adolescent males, by attitudes toward sexual behavior

\begin{tabular}{|c|c|c|c|c|c|c|}
\hline Statement & $\begin{array}{l}\text { Completely } \\
\text { agree }\end{array}$ & Agree & No idea & Disagree & $\begin{array}{l}\text { Completely } \\
\text { disagree }\end{array}$ & Total \\
\hline $\begin{array}{l}\text { Unmarried young people } \\
\text { should not have sex }\end{array}$ & 38.9 & 16.5 & 17.0 & 11.3 & 16.2 & 100.0 \\
\hline $\begin{array}{l}\text { Unmarried young people } \\
\text { should not even have }\end{array}$ & & & & & & \\
\hline opposite-sex friendships & 19.6 & 14.2 & 11.2 & 14.4 & 40.6 & 100.0 \\
\hline $\begin{array}{l}\text { Sexual relationships between } \\
\text { unmarried young people are } \\
\text { not acceptable even when }\end{array}$ & & & & & & \\
\hline they love each other & 46.1 & 15.0 & 18.4 & 8.6 & 11.9 & 100.0 \\
\hline Young women should not have & & & & & & \\
\hline sex before marriage & 56.1 & 11.5 & 16.8 & 5.4 & 10.1 & 100.0 \\
\hline Young men should not have sex & & & & & & \\
\hline $\begin{array}{l}\text { before marriage } \\
\text { Homosexual behavior }\end{array}$ & 41.0 & 13.8 & 16.6 & 11.6 & 16.9 & 100.0 \\
\hline is unacceptable & 69.2 & 7.2 & 10.4 & 2.7 & 10.5 & 100.0 \\
\hline
\end{tabular}




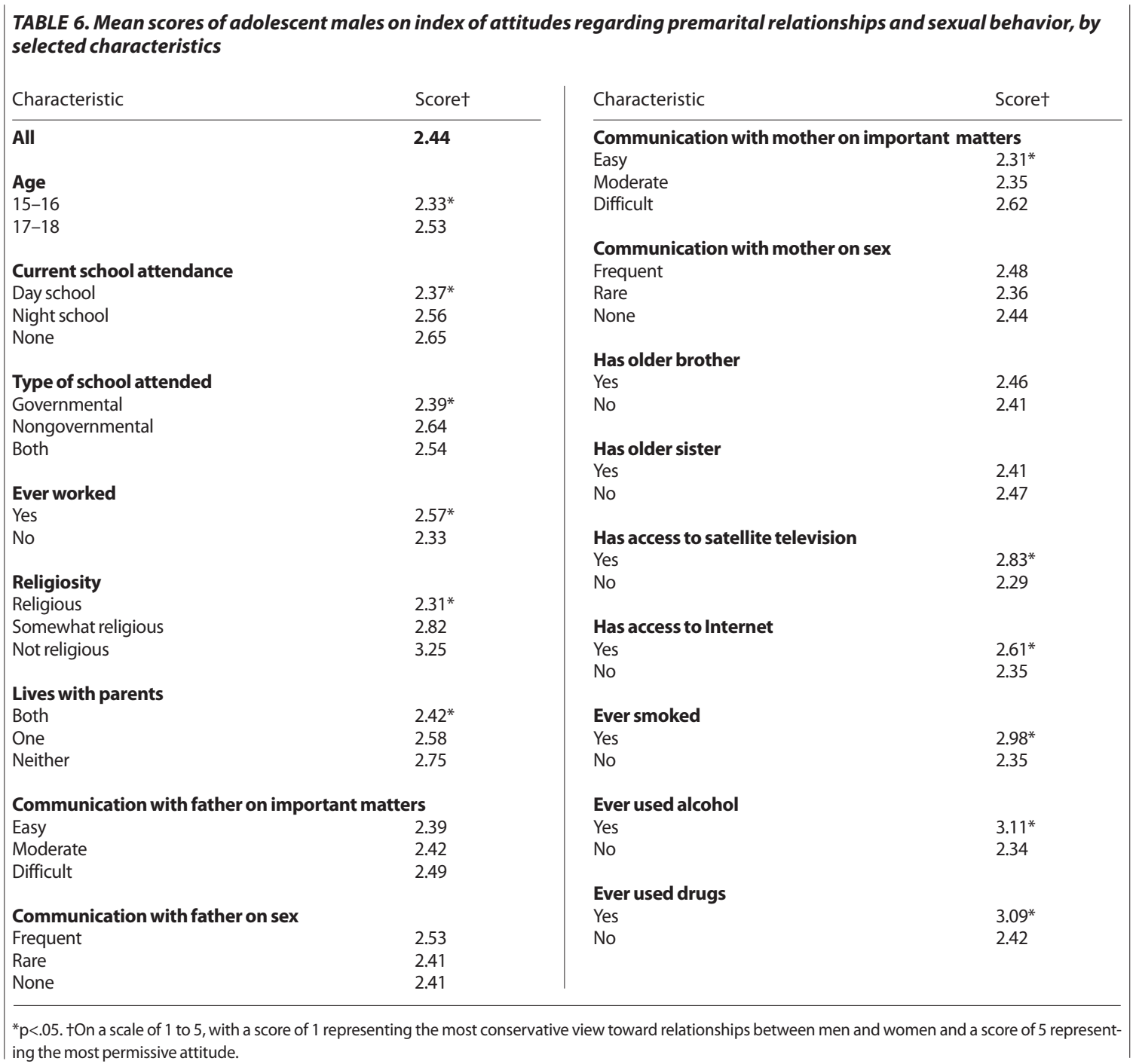

spondents, those not attending day school, those who studied in nongovernmental schools, those with work experience, and those not residing with both parents displayed relatively permissive attitudes toward premarital sex. Moreover, as expected, access to satellite television or the Internet, and use of cigarettes, alcohol or drugs, were associated with permissive attitudes, whereas religiosity was associated with conservative views. Although there was no link between frequency or ease of father-son communication and participant attitudes, respondents who reported difficulty in communicating with their mother on important matters were significantly more likely than others to report permissive attitudes.

\section{Sexual Experience}

As mentioned earlier, respondents were asked whether they had ever had "any sexual contact" (including both penetrative and nonpenetrative activity). In total, $28 \%$ of respondents reported ever experiencing sexual contact. Of these, more than half (55\%) said that their first such experience had taken place by age 15 (not shown). Partners were by and large older than the respondents: For example, while the mean age at first sexual contact among the young men was 14.8 ( $\mathrm{SD}=2.0$; range, 10 to 18 ), the mean age of their partners was $15.6(\mathrm{SD}=4.3)$ and $9 \%$ were 21 or older. Almost three-quarters (73\%) of those who had experienced sexual contact reported having had more than one partner in their lifetime.

Table 7 shows the proportion of respondents with any sexual experience, according to social and demographic characteristics. As expected, respondents who were older, those not currently in day school and those displaying low levels of religiosity were significantly more likely than others to report sexual experience. We also found increased levels of sexual activity among young males who had worked, a finding consistent with other studies in non-Western settings. ${ }^{8}$

Several family level factors were associated with sexual experience. Participants who did not reside with parents, those whose father was dead, and those who had an older brother or sister were more likely than other boys to report sexual activity. Adolescents who found it difficult to communicate with their fathers or mothers on important matters had higher rates of sexual contact, but so did those who communicated often with their parents on sexual matters. 
TABLE 7. Percentage of adolescent males who reported having sexual experience, by selected characteristics

\begin{tabular}{|c|c|c|c|}
\hline Characteristic & $\%$ & Characteristic & $\%$ \\
\hline \multirow[t]{2}{*}{ All } & 27.7 & Communication with mother on important matters & \\
\hline & & Easy & $24.3^{*}$ \\
\hline Age & & Moderate & 29.4 \\
\hline $15-16$ & $17.7^{*}$ & Difficult & 39.9 \\
\hline \multirow[t]{2}{*}{$17-18$} & 37.0 & & \\
\hline & & Communication with mother on sex & \\
\hline Current school attendance & & Frequent & $30.9^{*}$ \\
\hline Day school & $23.1^{*}$ & Rare & 25.6 \\
\hline Night school & 41.0 & None & 27.2 \\
\hline \multirow[t]{2}{*}{ None } & 42.9 & & \\
\hline & & Has older brother & \\
\hline Type of school attended & & Yes & $29.9^{*}$ \\
\hline Governmental & 27.5 & No & 25.0 \\
\hline Nongovernmental & 32.3 & & \\
\hline \multirow[t]{2}{*}{ Both } & 25.5 & Has older sister & \\
\hline & & Yes & $29.6^{*}$ \\
\hline Ever worked & & No & 25.1 \\
\hline Yes & $36.9^{*}$ & & \\
\hline \multirow[t]{2}{*}{ No } & 19.8 & Has access to satellite television & \\
\hline & & Yes & $48.4^{*}$ \\
\hline Religiosity & & No & 19.9 \\
\hline Religious & $23.2^{*}$ & & \\
\hline Somewhat religious & 43.4 & Has access to Internet & \\
\hline \multirow[t]{2}{*}{ Not religious } & 51.5 & Yes & $31.4^{*}$ \\
\hline & & No & 25.8 \\
\hline \multicolumn{4}{|l|}{ Lives with parents } \\
\hline Both & $26.2^{*}$ & Ever smoked & \\
\hline One & 38.7 & Yes & $58.0^{*}$ \\
\hline Neither & 44.4 & No & 23.3 \\
\hline Father & & Ever used alcohol & \\
\hline Alive & $27.0^{*}$ & Yes & $70.7^{*}$ \\
\hline Dead & 39.7 & No & 18.9 \\
\hline \multicolumn{2}{|l|}{ Communication with father on important matters } & Ever used drugs & \\
\hline Easy & $23.9^{*}$ & Yes & $55.2^{*}$ \\
\hline Moderate & 26.2 & No & 27.1 \\
\hline Difficult & 32.8 & & \\
\hline \multicolumn{4}{|l|}{ Communication with father on sex } \\
\hline Frequent & $34.0^{*}$ & & \\
\hline Rare & 22.5 & & \\
\hline None & 26.6 & & \\
\hline
\end{tabular}

Finally, access to the Internet and access to satellite TV were associated with having had sexual experience. As other studies have observed, youth who reported smoking, alcohol consumption or drug use were significantly more likely than others to report sexual contact.

We performed a logistic regression analysis to identify factors associated with sexual experience (Table 8, page 42). The strongest predictors of sexual experience were alcohol consumption and access to satellite television. As expected, respondents who were older, those who smoked and those with more permissive attitudes toward sex were more likely than others to have engaged in sexual activity.

\section{DISCUSSION}

In Iran, premarital sexual relations are strongly condemned. Within the jurisprudence of Shi'a Islam that governs Iran, marriage is required of everyone physically and financially suited to it; any sexual relationship before or outside marriage is considered illegitimate. It is generally assumed in Iranian society that sexual contact does not occur among unmarried adolescents. However, there has been some un- documented evidence that sexual relationships do occur among young people, especially now that technology is providing greater exposure to cultures with more permissive attitudes.

Our findings show that a substantial minority-more than one quarter — of adolescent males aged 15-18 in Tehran have had sexual contact (kissing, touching or sexual intercourse) with a woman. Although we were unable to obtain details regarding the nature of these contacts, the interviewer, when asked, explained that "sexual contact" meant sexual intercourse, and hence we believe that the majority of adolescents who acknowledged having sexual contact had in fact had intercourse. Moreover, given that any premarital sexual contact is culturally unacceptable in Iran, we believe that this variable is meaningful even if many respondents engaged only in nonpenetrative sexual activity. We were unable to determine whether the young men tended to overreport sexual experience.

The odds of sexual activity were significantly elevated among older adolescents, those who reported access to satellite television, those who had more permissive attitudes to- 


\begin{tabular}{|c|c|}
\hline Characteristic & Odds ratio \\
\hline \multicolumn{2}{|l|}{ Age } \\
\hline $15-16$ (ref) & 1.00 \\
\hline $17-18$ & $1.88(1.19-2.94)^{*}$ \\
\hline \multicolumn{2}{|l|}{ Current school attendance } \\
\hline Day school (ref) & 1.00 \\
\hline Night school/none & $1.44(0.91-2.29)$ \\
\hline \multicolumn{2}{|l|}{ Ever worked } \\
\hline No (ref) & 1.00 \\
\hline Yes & $1.85(0.58-5.85)$ \\
\hline \multicolumn{2}{|l|}{ Religiosity } \\
\hline Religious (ref) & 1.00 \\
\hline Somewhat religious/not religious & $1.64(0.98-2.73) \dagger$ \\
\hline \multicolumn{2}{|l|}{ Lives with parents } \\
\hline Both (ref) & 1.00 \\
\hline One/neither & $0.43(0.05-3.83)$ \\
\hline \multicolumn{2}{|c|}{ Communication with father on important matters } \\
\hline Easy (ref) & 1.00 \\
\hline Moderate/difficult & $1.19(0.75-1.90)$ \\
\hline \multicolumn{2}{|l|}{ Communication with father on sex } \\
\hline Rare/none (ref) & 1.00 \\
\hline Frequent & $1.70(0.80-3.61)$ \\
\hline \multicolumn{2}{|c|}{ Communication with mother on important matters } \\
\hline Easy (ref) & 1.00 \\
\hline Moderate/difficult & $1.00(0.61-1.64)$ \\
\hline \multicolumn{2}{|c|}{ Communication with mother on sex } \\
\hline Rare/none (ref) & 1.00 \\
\hline Frequent & $0.63(0.29-1.39)$ \\
\hline \multicolumn{2}{|l|}{ Has older brother } \\
\hline No (ref) & 1.00 \\
\hline Yes & $1.25(0.80-1.95)$ \\
\hline \multicolumn{2}{|l|}{ Has older sister } \\
\hline No (ref) & 1.00 \\
\hline Yes & $1.44(0.92-2.23)$ \\
\hline \multicolumn{2}{|l|}{ Has access to satellite television } \\
\hline No (ref) & 1.00 \\
\hline Yes & $2.22(1.36-3.62)^{* *}$ \\
\hline \multicolumn{2}{|l|}{ Has access to Internet } \\
\hline No (ref) & 1.00 \\
\hline Yes & $0.90(0.56-1.45)$ \\
\hline \multicolumn{2}{|l|}{ Ever smoked } \\
\hline No (ref) & 1.00 \\
\hline Yes & $2.19(1.14-4.18)^{*}$ \\
\hline \multicolumn{2}{|l|}{ Ever used alcohol } \\
\hline No (ref) & 1.00 \\
\hline Yes & $4.78(2.80-8.12)^{* *}$ \\
\hline \multicolumn{2}{|l|}{ Ever used drugs } \\
\hline No (ref) & 1.00 \\
\hline Yes & $0.31(0.04-2.24)$ \\
\hline \multicolumn{2}{|l|}{ Attitude towards sex‡ } \\
\hline Traditional (ref) & 1.00 \\
\hline Moderate/permissive & $1.97(1.28-3.04)^{*}$ \\
\hline Constant & 0.26 \\
\hline
\end{tabular}

ward sex and those who consumed alcohol or smoked. A significant relationship between alcohol use and sexual experience has been documented elsewhere. ${ }^{9}$ Two plausible explanations have been suggested for this association. First, substance use and premarital sex may both indicate a general inclination to take risks. Second, substance use tends to diminish both inhibitions and the ability to make rational decisions, thereby increasing the likelihood of sexual contact.

Our findings also suggest that sexual activity among Iranian adolescents takes place in a context in which awareness of health-promoting behaviors and communication on sexual matters with parents are moderate at best. Indeed, although most respondents (72\%) knew about condoms, many had misconceptions that could well discourage regular condom use. Consistent with these findings, a major source of information for adolescents on puberty and sexual matters was one that is likely to be unreliable-peers.

Respondents' attitudes toward premarital sex were, for the most part, moderate in an Iranian context. Indeed, between $15 \%$ and $27 \%$ disagreed with prohibitions against premarital sex and 13\% were tolerant of homosexual behavior. However, gender-based double standards persist. For example, although two-thirds of respondents agreed that females should not engage in sex before marriage, only half held the same view with regard to males. Similar double standards have been noted elsewhere. ${ }^{10}$ Our bivariate results suggest that attitudes were more permissive among adolescents who were older, out of school, or studying in nongovernmental schools, as well as those who had worked, resided separately from their parents, had access to the Internet or satellite TV, or used alcohol, cigarettes or drugs. In contrast, respondents who reported themselves to be highly religious displayed more traditional attitudes than others. Overall, these results suggest that a substantial minority of Iranian youth do not endorse traditional Iranian values and norms regarding sexual relationships.

It remains unclear to what extent the attitudes and behaviors of adolescent males in Iran have been influenced by their increasing access, via satellite television and the Internet, to other cultures with more permissive attitudes toward sex. The degree of access to satellite television that we observed (27\%) is likely an underestimate; respondents may have been reluctant to acknowledge having access to private satellite television because such access is legally restricted in Iran. In a study by Rouhani in 2000, some Iranian youth expressed concern that the Internet and satellite television could expose impressionable young people to pornographic material inconsistent with Iran's cultural and religious norms. ${ }^{11}$ However, only about one-fifth of young people surveyed for a recent National Youth Organization report said that they visited pornographic sites when they had Internet access (three-quarters of the visitors were male). ${ }^{12}$ Use of chat rooms was far more common, reported by nearly half of the Internet users in the study. Many young people use chat rooms to communicate with each other; therefore, Rouhani notes, the home computer "al- 
lows communication between unrelated men and women in a way that is not possible in public spaces."13

Despite the potential for the Internet and other technologies to influence attitudes and behaviors, the majority of Iranian families still believe that young people should wait until marriage to initiate sexual relationships. This view seems to be more rigid for girls rather than boys. More research is needed to explore youth norms and attitudes regarding sexual partnerships.

\section{CONCLUSIONS AND RECOMMENDATIONS}

We must acknowledge the limitations of this study and suggest that its findings be interpreted cautiously. Given Iran's conservative culture, we opted to use a self-administered questionnaire to assess the attitudes and behaviors of young males, but we were unable to engage participants in qualitative or in-depth discussions of youth norms or individual behaviors and experiences. Moreover, the questionnaire did not attempt to identify the precise sexual experiences of young men, nor did it attempt to gather detailed information about sexual partners. These constraints clearly limited the information we were able to obtain. Nevertheless, our findings suggest higher levels of sexual experience among adolescent males than has previously been assumed. Qualitative research is needed to gain a greater understanding of adolescent males' sexual behaviors. In addition, a similar quantitative study should be conducted among adolescent females.

What is clear from our findings is that even in Iran, a conservative society in which premarital sexual relations are prohibited, significant minorities of adolescent males do form relationships with young women and engage in sexual activity. Many hold permissive attitudes on the acceptability of premarital sex. At the same time, there is a general belief that adolescents should not engage in these behaviors. Such norms shape the nature of sexuality education provided to adolescents in Iran; indeed, it is widely assumed that providing formal sex education or accurate information about sexuality and reproduction may lead unmarried young people to initiate sexual relationships. As a result, information on contraceptive methods, reproductive physiology and condoms is rarely given to adolescents through the Iranian educational system.

Therefore, it is no surprise that adolescent males often have serious misconceptions about sexuality and reproduction, and are unprepared to make safe, informed decisions. Some of their primary sources of information, notably friends and classmates, are the most unreliable ones. Adolescent males themselves recognize their need for sexuality education and express a preference for obtaining this information from the educational sector, that is, from teachers and counselors. Adolescents need the school system to provide programs that address misconceptions about sexual and reproductive risks, encourage adolescents to make informed choices, emphasize parent-child communication and advocate gender equity in sexual and reproductive attitudes and behaviors.

The combination of permissive attitudes, sexual experimentation and lack of accurate information poses a sig- nificant threat to the sexual health of adolescent males in Iran and exposes them to risky sexual behaviors and their consequences. Our findings, while suggestive, argue for equipping adolescents with the information and skills to make safe sexual decisions.

\section{REFERENCES}

1. Statistical Centre of Iran, Iran Statistical Yearbook 2003: Population by Age and Sex, 1996 Census, <http://www.sci.org.ir/englishold/sel/f2/ S2_3S.htm>, accessed Jan. 25, 2006.

2. Aghajanian A and Mehryar AH, Fertility transition in the Islamic Republic of Iran, 1976-1996, Asia-Pacific Population Journal, 1999, 14(1)21-42.

3. Statistical Centre of Iran, Status of the Youth Nationwide, $<$ http://eamar.sci.org.ir/data.aspx?no=90913\&Ln=E\&S=GW>, accessed Jan. 25, 2006.

4. Malek Afzali H, Reproductive Health Need Assessment of Adolescent Boys in Iran, Tehran, Iran: Family Planning Association, 1998.

5. United Nations Population Fund (UNFPA), UNFPA Annual Report 1997, <http:// www.unfpa.org/about/report/report97/1997.htm>, accessed Mar. 3, 2006

6. Ingham R and Stone N, Topics for individual interviews and focus group discussions: partner selection, sexual behaviour and risk taking, in: Cleland J, Ingham R and Stone N, Asking Young People About Sexual and Reproductive Behaviours: Introduction to Illustrative Core Instruments, UNDP/UNFPA/WHO/World Bank Special Programme of Research, Development and Research Training in Human Reproduction: Geneva, <http://www.who.int/reproductive-health/ adolescent/questionnaire.html>, accessed Jan. 26, 2006.

7. Rouhani F, The Spatial Politics of Leisure: Internet Use and Access in Tehran, Iran, NMIT Working Paper, Washington, DC: Georgetown University, 2000, <http://nmit.georgetown.edu/papers/frouhani. htm>, accessed Jan. 26, 2005.

8. Abraham L and Kumar KA, Sexual experiences and their correlates among college students in Mumbai City, India, International Family Planning Perspectives, 1999, 25(3):139-146 \& 12; Lam TH, Stewart SM and Ho LM, Prevalence and correlates of smoking and sexual activity among Hong Kong adolescents, Journal of Adolescent Health, 2001, 29(5):352-358; Isarabhakdi P, Factors associated with sexual behavior and attitudes of never-married rural Thai youth, Journal of Population and Social Studies, 1999, 8(1):21-44; Meekers $\mathrm{D}$ and Ahmed G, Contemporary patterns of adolescent sexuality in urban Botswana, Journal of Biosocial Science, 2000, 32(4):467-485; and Magnani RJ et al., Reproductive health risk and protective factors among youth in Lusaka, Zambia, Journal of Adolescent Health, 2002, 30(1):76-86.

9. Jessor RJ, Problem Behaviors and Psychosocial Development. A Longitudinal Study of Youth, New York: Academic Press, 1977; Murray NJ et al., Gender differences in factors influencing first intercourse among urban students in Chile, International Family Planning Perspectives, 1998, 24(3):139-144 \& 152; Magnani RJ et al., 2002, op. cit. (see reference 8); Blum R and Mmari BRW, Risk and Protective Factors Affecting Adolescent Reproductive Health in Developing Countries, 2004, World Health Organization (WHO), <http://www.who.int/ child-adolescent-health/New_Publications/ADH/ISBN_92_4_ 159227_3.pdf>, accessed Jan. 25, 2005.

10. Waszak C, Thapa S and Davey J, The influence of gender norms on the reproductive health of adolescents in Nepal, perspective of youth, in: Bott $\mathrm{S}$ et al., eds., Towards Adulthood, Exploring the Sexual and Reproductive Health of Adolescents in South Asia, Geneva: WHO, 2003.

11. Rouhani F, 2000, op. cit. (see reference 7).

12. Ahmadpour MH, Preliminary Report on Nature of Access to Internet Among Young People in Iran, Tehran, Iran: National Youth Organization, 2005.

13. Rouhani F, 2000, op. cit. (see reference 7). 


\section{RESUMEN}

Contexto: La cultura y la religión en Irán prohíben el contacto sexual antes del matrimonio. Se sabe muy poco acerca de la actividad sexual de los adolescentes solteros varones o sobre su conocimiento y actividades con respecto a la salud sexual y reproductiva.

Métodos: Un estudio realizado con base en la población de 1.385 hombres, de 15-18 años, en Terán, fue realizado mediante el uso de un cuestionario autoadministrado. Se les preguntó a los participantes acerca de sus creencias sobre la salud reproductiva y si habian mantenido alguna actividad sexual. Se realizaron análisis de dos variables y de variables múltiples para identificar los factores relacionados con el conocimiento, las actitudes y el comportamiento con respecto al sexo.

Resultados: El veintiocho por ciento de la muestra indicó que había participado en alguna actividad sexual. La experiencia sexual estuvo relacionada con una edad mayor de los entrevistados, el acceso a la televisión vía satélite, el consumo de alcohol y a actividades permisivas con respecto al sexo. Un porcentaje considerable de entrevistados tenía conocimientos erróneos con respecto al uso del condón, las ETS y la fisiología reproductiva. Las actitudes hacia las relaciones previas al matrimonio eran de mayor tolerancia entre las personas entrevistadas que eran mayores de edad, no estudiaban, tenían experiencia de trabajo, acceso a Internet o a la televisión vía satélite, no vivían con sus padres, que habian consumido alcohol, cigarrillos o drogas.

Conclusión: La prevalencia relativamente elevada de actividad sexual y la falta de conocimientos sobre las ETS y los anticonceptivos constituyen una amenaza significativa para la salud sexual y reproductiva de los hombres adolescentes en Irán. Es necesario contar con programas que ofrezcan a los adolescentes la información y la capacidad para adoptar decisiones adecuadas en materia sexual.

\section{RÉSUMÉ}

Contexte: La culture et la religion iraniennes interdisent le contact sexuel prénuptial. L'activité sexuelle des adolescents célibataires de sexe masculin et leurs connaissances et attitudes à l'égard de la sexualité et de la santé génésique sont peu documentées.

Méthodes: Une étude en population générale de 1.385 jeunes hommes âgés de 15 à 18 ans à Téhéran a été menée au moyen d'un questionnaire autoadministré. Les participants ont été interrogés sur leurs croyances et connaissances en matière de santé génésique, ainsi que sur leur expérience sexuelle. Les facteurs associés à la connaissance, aux attitudes et comportement sexuels ont été identifiés par analyses bi-et multivariées.

Résultats: Vingt-huit pour cent des jeunes hommes de l'échantillon ont déclaré s'être engagés dans une activité sexuelle. L'expérience sexuelle s'est révélée associée à un âge plus avancé, à l'accès à la télévision par satellite, à la consommation d'alcool et à des attitudes permissives à l'égard du sexe. Les répondants se faisaient, en proportions substantielles, une idée fausse du préservatif, des IST et de la physiologie de la reproduction. Les attitudes à l'égard des rapports sexuels prénuptiaux se sont révélées plus permissives parmi les répondants plus âgés, non scolarisés, ayant une expérience professionnelle, disposant d'un accès à Internet ou à la télévision par satellite, ne vivant pas avec leurs parents ou ayant déclaré avoir bu de l'alcool, fumé des cigarettes ou s'être drogués.

Conclusion: La prévalence relativement élevée de l'activité sexuelle et l'ignorance concernant les IST et la contraception posent un danger significatif pour la santé sexuelle et génésique des jeunes hommes iraniens. Il existe un besoin de programmes aptes à apporter aux adolescents l'information et les compétences nécessaires à la prise de décisions sexuelles dénuées de risque.

\section{Acknowledgments}

This study was supported by a grant from the Department of Reproductive Health and Research, World Health Organization. The authors are grateful for generous support and guidance from Shireen J. Jejeebhoy. The authors also thank Professor John Cleland, Centre for Population Studies, London School of Hygiene and Tropical Medicine, for his valuable comments and assistance in preparing the article.

Author contact: farideh.farahani@lshtm.ac.uk 